\title{
B.И. ДЕНИСОВ
}

\section{Россия и Корейский полуостров в новой международной ситуации}

\author{
Денисов Валерий Иосифович, д.и.н., Чрезвычайный и Полномочный Посол, \\ главный научный сотрудник Центра исследований Восточной Азии \\ и ШОС ИМИ МГИМО (У) МИД России, посол РФ в КНДР(1996-2001). \\ 119454, Москва, просn. Вернадского, 76._E-mail: valery_denisov@mail.ru
}

\begin{abstract}
Аннотация
В статье рассматриваются новейшие тенденции в международной обстановке вокруг Корейского полуострова и политика главных акторов. США стремятся упрочить свое военно-политическое присутствие в Южной Корее, а Сеул рассчитывает пересмотреть прежние соглашения с США в области атомной энергетики. Усиливается трехстороннее взаимодействие (США-Япония-РК) по северокорейской ядерной проблеме. Политика США в отношении КНДР остается конфронтационной и имеет целью противостоять усилению Китая и России в этом регионе. В то же время США поддерживают межкорейский диалог, одновременно пытаясь в коалиции со странами Запада оказывать давление на КНДР по проблемам прав человека и в области денуклеаризации.

Пхеньян обеспокоен военным сближением между РК и США, пытаясь сделать свою ядерную программу предметом торга в корейском урегулировании. Межккорейские отношения по-прежнему носят характер военно-политического противостояния, несмотря на постоянные призывы к мирному воссоединению, развитию экономических и культурных связей. Анализ показывает, что КНДР и РК далеки от реального прогресса в этом отношении.

Китайский фактор остается существенным, но поведение Пекина отличается осторожностью. Налицо ослабление политических контактов и экономических связей между КНДР и КНР после прихода к власти Ким Чен Ына. Пхеньян обеспокоен регулярными контактами между КНР и США по северокорейской проблематике. Осложнение международной обстановки не привело к спаду в отношениях Пекина с Сеулом, хотя КНР выступает против размещения в РК противоракетных комплексов. Корейская политика Пекина направлена на сохранение статус-кво на полуострове и недопущение коллапса северокорейского режима.

Корейская политика РФ неизменно базируется на сформулированных в 2001 г. установках. В последнее время КНДР стремится к активизации политического диалога с Россией, $а$ РК не проявляет прежнего интереса к расширению сотрудничества. В российской политике на корейском направлении, по мнению автора, необходимо продвигать шестисторонний переговорный процесс, не допускать перегибов в подходах к обоим корейским государствам и противодействовать доминированию США в регионе.
\end{abstract}

Ключевые слова: КНДР, Южная Корея, межкорейский диалог, денуклеаризация, США, КНР, Россия, ПРО. 
Опасный скачок напряжённости в мире оказывает негативное влияние на обстановку на Корейском полуострове. Предпринимавшиеся в течение нескольких лет усилия дипломатическими средствами решить корейский ядерный кризис, возобновить шестисторонний (РФ, КНР, США, Япония, КНДР, РК) переговорный процесс оказались безуспешными. С конца 2008 г. шестисторонние переговоры прекращены. США и их союзники (Япония, Южная Корея) под различными предлогами противятся диалогу, требуют от Пхеньяна «реальных шагов» по денуклеаризации, прекращения ракетно-ядерных испытаний. КНДР со своей стороны настаивает на снятии санкционного режима, отмене многочисленных военных манёвров, проводимых США и РК на юге Корейского полуострова.

США последовательно проводят линию на упрочение своего военно-политического присутствия и расширения влияния в Южной Корее. В последнее время Вашингтон уделяет первостепенное внимание укреплению американоюжнокорейских союзных отношений, наращиванию мощи вооружённых сил двух стран, интенсификации совместных военных учений, что, по замыслам американских генералов, позволит успешно противостоять Северной Корее.

Несмотря на противодействие России и Китая, Пентагону удалось добиться согласия южнокорейского руководства на развёртывание элементов американской системы противоракетной обороны на территории РК (комплекс THAAD), хотя Сеул всячески отрицает такие договорённости. Факты, однако, говорят о противоположном. Представители Южной Кореи продолжают лукавить, утверждая, что они обсуждают с США проблему ПРО в контексте укрепления безопасности в данном регионе, но не ведут консультаций относительно размешения противоракетных комплексов THAAD на юге Корейского полуострова.

В качестве компенсации США согласились отложить передачу Сеулу опера- тивного контроля над американскими вооружёнными силами в военное время. Южная Корея долго и настойчиво стремилась отнести на неопределённые сроки решение данной проблемы. Первоначально передача планировалась на 2011 г., затем была перенесена на 2015 г. Сегодня о сроках вообще ничего не говорится, а лишь констатируется, что решение будет принято, «когда для этого сложатся необходимые условия». Под «необходимыми условиями» американские и южнокорейские генералы понимают установление стабильности и безопасности на Корейском полуострове и в регионе, а также приемлемое состояние боеготовности вооружённых сил РК. Южная Корея и США приняли решение создать объединённую дивизию «для выполнения особых задач в военное время». В январе 2015 г. штаб объединённой дивизии приступил к работе. В марте дивизия участвовала в совместных американо-южнокорейских учениях.

В течение длительного времени Сеул добивается пересмотра соглашения с США в области атомной энергетики, требует предоставить ему право переработки отработанного ядерного топлива в Южной Корее. Переговоры по соглашению ещё не завершены. Однако в южнокорейских СМИ появляются сообщения о том, что результаты переговоров могут быть успешными для Сеула. Если документ будет подписан, то это отход Вашингтона от прежней позиции, запрещавшей южным корейцам переработку отработанного ядерного топлива на собственной территории. Учитывая большой интерес Сеула к данному вопросу и его неоднократные попытки в недавнем прошлом «проводить опыты» с отработанным ядерным топливом, новые договоренности, несомненно, осложнят ситуацию на Корейском полуострове и создадут дополнительные преграды на пути денуклеаризации этого региона.

Соединённые Штаты заметно усилили внимание к укреплению трёхстороннего взаимодействия (США-Япо- 
ния-РК) по корейской проблеме, её различным аспектам, прежде всего ядерному. Серьёзную озабоченность США вызывают распри между их главными союзниками в Азиатско-Тихоокеанском регионе. Сеул и Токио продолжают острую полемику по ряду проблем двусторонних отношений (территориальное размежевание, колониальное прошлое и др.), что, по мнению американцев, ослабляет усилия Вашингтона по противодействию России и Китаю в регионе и ракетно-ядерным угрозам КНДР. Под нажимом США продолжается укрепление трёхстороннего взаимодействия по северокорейской ядерной проблеме. В рамках трёхстороннего формата активизировалось обсуждение совместных шагов в отношении КНДР, её ракетно-ядерной деятельности. Между военными ведомствами трёх стран подписано соглашение об обмене информацией по Северной Kopee, её военным программам.

Политика США в отношении Северной Кореи остаётся жёстко конфронтационной. Вашингтон ввёл дополнительные санкции против Пхеньяна, обвинив его в организации хакерской атаки на кинокомпанию «Sony Pictures». США отвергли предложение КНДР провести совместное расследование этого инцидента. В вооружённых силах США, расквартированных в Южной Корее, создано специальное подразделение, в задачу которого входит взятие под контроль северокорейских ядерных объектов в случае чрезвычайных обстоятельств. В ходе проводимых на Юге американо-южнокорейских учений «Key Resolve» это подразделение отрабатывает выполнение указанной задачи.

Периодически из Вашингтона раздаются призывы к примирению с КНДР, в поддержку межкорейского диалога и т.п. Официальные американские деятели заявляют, что США не собираются предпринимать акций, ведущих к смене политического режима в Северной Корее, готовы к установлению мирных отношений с Пхеньяном, заключению соглашения о ненападении и даже сокращению американских войск на юге полуострова, но при одном условии: КНДР должна осуществить денуклеаризацию, т.е. ликвидировать свои ракетно-ядерные программы. Представители Северной Кореи отвергают это условие и в свою очередь требуют отмены санкций, прекращения американских враждебных действий в отношении КНДР. Правительство США приняло решение прекратить оказание КНДР гуманитарной продовольственной помощи до тех пор, пока Пхеньян не закроет ракетно-ядерные программы. США, как сообщают СМИ, рассматривают вопрос о возвращении КНДР в список спонсоров терроризма, из которого она была исключена в 2008 г.

Жёсткому международному давлению подвергается КНДР по проблеме прав человека. Доклад специальной комиссии ООН, осуждающий нарушение прав человека в Северной Корее, был подготовлен по инициативе США, РК, стран Запада и собрал в ООН 116 голосов («против» - всего 20, при 53 воздержавшихся). Правозащитная тематика стала ещё одним серьёзным рычагом давления на Пхеньян в попытках расшатать политический режим в этой стране, ослабить позиции молодого северокорейского руководителя в условиях перманентных социально-экономических трудностей. Под предлогом нарушения прав человека, продолжения ракетноядерных программ США и их союзники добились резкого сокращения объёмов международной гуманитарной помощи Северной Kopee. В 2014 г. эта помощь составила около 30 млн долл., что в 10 раз меньше, чем в предыдушие годы. Судя по всему, правозащитная тематика останется одним из мощных средств политико-дипломатического давления Запада на КНДР в обозримой перспективе.

В начале текущего года Пхеньян сделал США интересное, на наш взгляд, предложение: в обмен на приостановку ядерных испытаний в КНДР отменить американо-южнокорейские учения. 
Представители КНДР и США в янваpe 2015 г. в неофициальном порядке провели в Сингапуре обсуждение этого и других предложений по урегулированию корейского вопроса. Однако администрация Б. Обамы отвергла северокорейскую инициативу, усмотрев в ней «скрытую угрозу» [1]. Ряд экспертов тем не менее полагают, что северокорейская идея заслуживает внимания и конкретного рассмотрения и Вашингтон зря с ходу отверг её.

В условиях обострения международной обстановки США очень внимательно отслеживают ситуацию на Корейском полуострове, сохраняют высокую степень боеготовности своих вооружённых сил в Северо-Восточной Азии. Северокорейская линия поведения Вашингтона концентрируется на том, чтобы попытаться «додавить» пхеньянский режим путём наращивания политических, финансово-экономических санкций, ужесточения мер военного характера.

Межкорейские отношения в нынешний период нарастания международной нестабильности по-прежнему носят характер жёсткого военно-политического противостояния. Вместе с тем со стороны обоих корейских государств звучат призывы к мирному воссоединению, денуклеаризации полуострова, развитию экономических и культурных связей. КНДР предложила провести в 2015 г. - в год 70-летия освобождения Кореи от японского колониального господства - межкорейский саммит. Однако Пхеньян и Сеул обставляют свои предложения предварительными условиями. КНДР требует прекращения американо-южнокорейских учений, отмены антисеверокорейских санкций, прекращения запусков на Север антиправительственных листовок и т.д. Сеул настаивает на ликвидации ракетно-ядерных программ КНДР, организации регулярных встреч разлучённых родственников, обещает крупную экономическую помощь в случае прогресса в межкорейских отношениях. В Южной Корее создан специальный Комитет по объединению Кореи, в который приглашены авторитетные политические фигуры из-за рубежа, известные политологи и эксперты по корейским делам. Возглавляет Комитет президент PK Пак Кын Хе. Задача этого органа, как её понимают в Сеуле, - готовить предложения для продвижения идеи мирного объединения Кореи.

Южнокорейское правительство приняло решение разработать закон «О создании основ для мирного воссоединения». По случаю 70-летия освобождения Кореи в РК планируется серия политических и культурных мероприятий, в том числе и с северокорейцами. Сделать это будет непросто, учитывая напряжённость в межкорейских отношениях.

Анализ предлагаемых корейскими сторонами мер по оздоровлению отношений показывает, что КНДР и РК далеки от реального прогресса. Во-первых, многие из этих мер уже не раз выдвигались сторонами ранее и были отвергнуты. Во-вторых, в подходы Пхеньяна и Сеула закладываются такие идеи, которые априори неприемлемы ни для той, ни для другой стороны. В-третьих, в позициях сторон всегда присутствует нескрываемая тактика перехитрить, обмануть партнёра. Кроме того, Пхеньян в диалоге с южанами не стесняется дороже продать своё согласие с тем или иным предложением Сеула. Северокорейским высокопоставленным чиновникам удалось «заработать» 500 млн долл. в казну режима Ким Чен Ира на визите президента РК Ким Дэ Чжуна в Пхеньян в 2000 г. Власти КНДР пытались организовать межкорейский саммит, когда на Юге у власти находился президент Ли Мён Бак (2008-2013 гг.). При этом они запросили астрономическую цену за встречу руководителей двух Корей (400 тыс. тонн риса, 100 тыс. тонн кукурузы, 300 тыс. тонн удобрений, 10 млрд долл. на создание «банка развития КНДР», а в реальности - для пополнения личной кассы северокорейского вождя). Ли Мён Баку было не под силу выполнить эти запро- 
сы Пхеньяна, и он отказался от встречи с Ким Чен Иром. В настоящее время обе корейские стороны не готовы к продуктивному диалогу. Кроме того, надо иметь в виду, что США зорко наблюдают за всеми перипетиями межкорейского общениями и больше не допустят попыток примирения, которые были предприняты Севером и Югом в период нахождения у власти президентов Ким Дэ Чжуна и Но Му Хёна.

Китайский фактор в современных условиях возрастания международной напряжённости по-прежнему играет существенную роль в корейских делах. Пекин ведёт себя в отношении Пхеньяна и Сеула достаточно осторожно. Китайцам многое не нравится в поведении как Севера, так и Юга. КНР весьма озабочена тем, что её усилия по разрешению ядерной проблемы фактически потерпели фиаско. Новый северокорейский руководитель проигнорировал советы своего старшего брата и союзника, что идёт вразрез с традициями конфуцианства, осуществил испытание в 2013 г. ядерного устройства, провёл серию пусков баллистических ракет. Значительную долю напряжения в отношения КНДР-КНР привнесла казнь одного из высших руководителей КНДР Чан Сон Тхэка, которого в Пекине считали одним из тех деятелей, кто последовательно выступал за углубление северокорейско-китайских отношений. Поездка в Пекин в мае 2013 г. специального посланника лидера КНДР Цой Рён Хэ не привела к потеплению отношений между КНДР и Китаем. Пхеньян, однако, публично заявил о готовности к возобновлению шестисторонних переговоров по разрешению ядерного кризиса без всяких условий. США, РК и Япония усомнились в искренности Пхеньяна и потребовали не на словах, а на деле доказать серьёзность его намерений в деле денуклеаризации Корейского полуострова.

Северная Корея и Китай заметно сократили делегационный обмен. Южные корейцы, внимательно наблюдающие за всеми перипетиями северокорейско- китайских отношений, отмечают, что после прихода к власти Ким Чен Ына в три раза уменьшилось число политических контактов между двумя странами и туристических поездок. За три года пребывания у руля КНДР Ким Чен Ын ни разу не встретился с председателем КНР Си Цзиньпином, в то время как президент РК Пак Кын Хе в течение двух лет провела пять встреч с китайским лидером. В Пекине, судя по всему, озабочены этим вопросом. В марте 2015 г. министр иностранных дел КНР Ван И заявил о возможности встречи руководителей Китая и Северной Кореи. По его словам, обе стороны прилагают усилия к укреплению китайско-северокорейских отношений.

КНДР очень настороженно относится к происходящим в Китае дискуссиям, которые касаются ситуации на Севере, Корейском полуострове в целом, ядерного вопроса. Периодически в китайских СМИ звучат призывы «бросить Северную Корею», появляются мнения о том, что Китай - не спаситель КНДР, он не должен вмешиваться, если на полуострове разразится война; что ответственность должен нести тот, кто спровоцирует войну; что Китай не должен воевать за другую страну. Подобные публикации отражают недовольство руководства КНР поведением молодого лидера Северной Кореи, особенно в ракетно-ядерной области.

КНДР и Китай существенно сократили торгово-экономические связи. Хотя $90 \%$ северокорейского товарооборота по-прежнему приходится на КНР, однако его объёмы заметно упали: с 5,6 млрд долл. в 2011 г. до 2,8 млрд в 2014 г. Пекин уменьшил поставки в Северную Корею сырой нефти, авиационного топлива и других видов нефтепродуктов.

Рост напряжённости на Корейском полуострове вызывает ответные военные меры со стороны Китая. Пекин активизировал проведение военных учений вблизи границ с КНДР. В октябре 2014 г. проведены манёвры с участием 20 тыс. военнослужащих Народно-осво- 
бодительной армии Китая. Как отмечают эксперты, в ходе учений отрабатывались варианты высадки на Корейский полуостров. В январе 2015 г. Китай провёл манёвры в районе горы Пэктусан, дважды священной для северных корейцев (согласно официальной теории, в 2033 г. до н.э. там было создано первое на территории Корейского полуострова государство - Древний Чосон, - и там же в 30-е годы XX в. вёл антияпонскую партизанскую борьбу основатель КНДР Ким Ир Сен). В районе Пэктусана, как сообщают мировые СМИ, Китай разместил баллистические ракеты средней дальности «Dongfeng-21», которые способны поражать цели не только в Южной Kopeе, но и в Японии и даже достигать острова Гуам. Всё это вызвало обеспокоенность в правящих кругах Южной Кореи и Японии.

Пхеньян сильно обеспокоен регулярными контактами между КНР и США по северокорейской тематике. В КНДР опасаются, что две сверхдержавы могут заключить некую сделку за счёт интересов Северной Кореи. Американцы постоянно раскручивают тему «позитивного вклада» Китая в международные усилия по разрешению ядерного кризиса, вклад этот выражается в нарастающем давлении Пекина на КНДР с целью побудить её пойти на денуклеаризацию полуострова.

Несмотря на сложности в северокорейско-китайских отношениях, публичную критику Китаем ядерных амбиций Пхеньяна, введение им ограничительных мер в отношении своего союзника, китайцы осознают стратегическую значимость КНДР для КНР, китайской политики в Северо-Восточной Азии. Подобные охлаждения и даже проявления открытой враждебности (в период «культурной революции» в Китае) не раз имели место в отношениях двух стран. Но сторонам удавалось преодолевать их. Вероятно, и на этот раз Пхеньян и Пекин найдут способы устранения существующих трудностей и выйти на приемлемые компромиссы. В этом контексте обращает на себя вни- мание поддержка Китаем северокорейского предложения о прекрашении совместных американо-южнокорейских маневров в обмен на отсрочку ядерных испытаний в КНДР. По мнению Пекина, инициатива КНДР направлена на улучшение северокорейско-американских отношений. Несогласие США с предложением КНДР в Пекине квалифицируют как отказ от «налаживания доверительных отношений на Корейском полуострове».

Осложнение современной международной обстановки не привело к спаду в отношениях Пекина с Сеулом. Стороны сохраняют высокий уровень политического диалога, расширяют торговоэкономические связи, растут объёмы инвестиционного сотрудничества. Китай ведёт сложную борьбу с США за влияние на Южную Корею, стремится ослабить американское присутствие в этой стране. КНР и РК установили стратегический диалог, который охватывает широкий круг вопросов сотрудничества в политической, экономической, военной, гуманитарной и других сферах. Недавно стороны открыли новый канал диалога по вопросам безопасности. При обсуждении проблем безопасности Пекин делает акцент на недопущении размещения на Юге американской системы глобальной ПРО, считая, что противоракетные комплексы THAAD нацелены на Китай, а не на Северную Корею, как утверждают США. Во время визита в Сеул в феврале 2015 г. министра обороны КНР Чан Ваньцюаня проблема ПРО конкретно обсуждалась как на переговорах с министром обороны РК Хан Мин Гу, так и на встрече китайского министра с президентом Пак Кын Хе. После окончания визита Чана в Сеул южнокорейская сторона официально заявила, что не обсуждает с США возможность размешения на юге Корейского полуострова мобильных комплексов американской противоракетной системы THAAD. Но здесь Сеул снова лукавит. Ешё в 2013 г. РК и США вели разговор о возможности размещения комплексов THAAD на 
Юге. По словам министра обороны РК Хан Мин Гу, данный комплекс будет весьма полезен для укрепления обороноспособности Южной Кореи. Кроме того, Пентагон добивается финансового вклада Сеула в наращивание мощи американских вооружённых сил на острове Гуам, где планируется дополнительно разместить противоракетные комплексы THAAD.

Постоянное лукавство южнокорейской стороны по данному вопросу вызывает раздражение в Пекине. Спустя некоторое время после визита в РК министра обороны Чан Ваньцюаня Китай официально выразил надежду на то, что Южная Корея «отнесётся к вопросу размещения THAAD на своей территории серьёзно и обдуманно, поскольку это может серьёзно отразиться как на безопасности в регионе, так и на китайско-южнокорейских отношениях» [2]. Предупреждение весьма своевременное. Сеулу нужно крепко задуматься над возможными последствиями.

Южнокорейская реакция последовала незамедлительно. Сеул договорился с Пентагоном не комментировать вопрос о THAAD. Правящая партия потребовала срочно обсудить данную проблему с правительством. Пытаясь снять возникшую напряжённость, министерство обороны РК заявило, что у него нет планов закупки противоракетных комплексов THAAD.

Пекин и Сеул проводят регулярные консультации по вопросу созыва шестисторонних переговоров, декларируют заинтересованность в скорейшей денуклеаризации Корейского полуострова, однако позиции сторон серьёзно разнятся.

Экономические связи между двумя странами уверенно набирают обороты. В 2014 г. взаимная торговля составила 230 млрд долл., в 2015 г. запланировано достичь 300 млрд долл. С 2015 г. между PK и Китаем начинает действовать соглашение о свободной торговле. Южнокорейские инвестиции в китайскую экономику постоянно растут. В 2014 г. они увеличились на $30 \%$, составив по- чти 4 млрд долл. Расширяется сотрудничество в области науки, культуры, образования, туризма.

Пекин выражает поддержку межкорейского диалога, мирного объединения Севера и Юга. В Китае приветствовали предложения лидеров корейских государств об организации межкорейского саммита, выдвинутые в новогодних обрашениях руководителя КНДР Ким Чен Ына и президента РК Пак Кын Хе.

Корейская политика Пекина, несмотря на рост напряжённости в различных регионах мира, сбои на северокорейском направлении, ориентирована на сохранение статус-кво, обеспечение стабильности на Корейском полуострове, поиск политического урегулирования ядерной проблемы КНДР. Пекин стремится к тому, чтобы не допустить коллапса северокорейского режима. Реализация этих задач, как представляется, будет оставаться одним из главных приоритетов политики Пекина в Азиатско-Тихоокеанском регионе в обозримой перспективе.

На протяжении последних 15 лет корейская политика Российской Федерации базируется на сформулированных В.В. Путиным в феврале 2001 г. установках, которые включают следующие моменты: мирное решение проблем полуострова; межкорейское примирение; безъядерный статус, ракетное нераспространение; взаимовыгодное экономическое сотрудничество, в том числе с участием России; создание в перспективе единой демократической Кореи, дружественно настроенной в отношении соседей, проводящей миролюбивую политику.

Новый концептуальный подход России к развязке застарелого и сложного корейского узла позволил восстановить позиции и авторитет Москвы на Корейском полуострове, укрепить отношения равноправного и взаимовыгодного сотрудничества с обоими корейскими государствами, освободиться от прежних ельцинских несуразностей в нашей политике в данном регионе. Россия внесла 
и продолжает вносить реальный вклад в поиск политических средств разрешения корейского ядерного кризиса, не раз отводила угрозу сползания корейских сторон к военному конфликту с непредсказуемыми последствиями.

Ухудшение отношений России с западным миром, введение жёстких антироссийских санкций привело к изменениям поведения Пхеньяна и Сеула в отношении Москвы. Если КНДР проявила желание к активизации политического диалога и практических связей с нами в различных областях, то Южная Корея под строгим оком американского союзника притаилась и не проявляет прежнего интереса к расширению сотрудничества. Южнокорейские представители заверяли нас, что не намерены поддерживать антироссийские санкции США и Евросоюза. Однако на деле получилось иначе. Высокопоставленные чиновники РК признали, что Южная Корея частично присоединилась к санкциям [3].

Сеул тянет с ответом на приглашение российской стороны президенту РК прибыть в Москву для участия в мероприятиях по случаю 70-летия Победы в Великой Отечественной войне и, судя по всему, Пак Кын Хе вряд ли приедет на московские торжества, ведь Б. Обама уже ответил отказом. Здесь нельзя не вспомнить, что ее отец Пак Чжон Хи доставлял немало хлопот США, проявлял строптивость, пытался обхитрить союзника, за что и поплатился жизнью (в Южной Корее до сих пор убеждены, что Пак Чжон Хи был устранён американцами за «неспособность» обеспечить интересы США). Чтобы лишний раз напомнить Сеулу и другим сателлитам США о «союзнической солидарности», Вашингтон призвал дать единый ответ на события на Украине и не участвовать в майских торжествах в Москве. Президент РК Пак Кын Хе, как известно, уклонилась и от участия в церемонии открытия Олимпийских игр в Сочи в 2014 г. Причина вполне понятна - её шеф Б. Обама воздержался от поездки в Сочи. Правда, здесь есть один суще- ственный нюанс: в Россию на 9 мая собирается руководитель КНДР Ким Чен Ын. Во всяком случае, это официально подтвердили в Москве. В связи с этим в мировых СМИ, особенно в южнокорейских, стали строить предположения о возможной встрече в Москве Кима и Пак. Конечно, в политике могут быть всякие неожиданности. Но, насколько известно, лидеры КНДР и РК не раз приглашались на различные мероприятия в Москву. Ким Ир Сен, например, вообще не любил «многосторонние посиделки» и также предпочитал воздерживаться от поездок на подобные торжества. Поэтому поедет ли новый руководитель КНДР в Россию именно на 9 мая - это вопрос, на который нет определённого ответа. Ведь корейцы, как северные, так и южные, большие мастера «наводить тень на плетень», любители решать щекотливые вопросы за кулисами, без лишнего шума и постороннего глаза. Кстати говоря, практически все межкорейские договорённости на правительственном уровне достигались в ходе секретных встреч и переговоров. Это - одна из характерных черт ментальности корейцев. Нельзя также не учитывать здесь возможную негативную реакцию Китая. Может быть, это очередная северокорейская уловка - попытаться насолить китайским товарищам, показать им, что у Пхеньяна есть альтернатива стратегическому союзу с КНР и он готов сменить внешнеполитические приоритеты. В общем, вопрос о поездке в Москву корейских вождей остаётся открытым.

Введение Западом антироссийских санкций отразилось и на подходе Сеула к экономическому сотрудничеству с Россией. Здесь также не обошлось без вмешательства Вашингтона. Его эмиссар специально посетил ряд стран СВА, включая КНР, Японию и Южную Корею, чтобы убедить их присоединиться к санкциям. Сеул и Токио, хотя и с оговорками, поддержали США. Надо сказать, что южнокорейские промышленные круги всегда смотрели на экономическое сотрудничество с нашей 
страной подозрительно, постоянно указывали нам на всевозможные препятствия (в большинстве своем - надуманные), существующие в России для развития бизнеса. Главная же причина - нежелание Сеула создавать в лице российского бизнеса ещё одного конкурента (помимо Китая и Японии) в Северо-Восточной Азии.

Прошедший в конце 2014 г. в Сеуле российско-южнокорейский экономический форум продемонстрировал намерение России широко открыть двери для сотрудничества с РК, другими странами АТР. Нас особенно интересует взаимодействие с Сеулом в области судостроения. Однако представители Южной Кореи дали понять, что эта отрасль вряд ли может быть предметом сотрудничества.

В целом же экономические связи с Южной Кореей у России складываются неплохо. В России работает более 600 южнокорейских компаний. Увеличивается товарооборот (в 2014 г. - более 20 млрд долл.). Инвестиции пока небольшие (3 млрд долл.). В обешание же Южной Кореи в ближайшие годы вложить в экономику российского Дальнего Востока 1 млрд долл. верится с трудом. Сеул не раз обещал и подписывал разного рода документы, меморандумы Многое из обещанного так и осталось на бумаге.

У России с корейцами Севера и Юга неплохие перспективы для трёхстороннего экономического взаимодействия в области логистики (доставка российского угля из северокорейского порта Рачжин в Южную Корею), энергетики, железнодорожного транспорта и т.д. Всё зависит от ситуации на Корейском полуострове, состояния межкорейских отношений, разрешения ядерного кризиса.

Оживление политических контактов, налаживание экономических связей между Россией и КНДР нельзя не приветствовать, особенно в нынешнее непростое и для Москвы, и для Пхеньяна время. Визиты в Москву спецпосланника руководителя КНДР Ким Чен Ына и министра иностранных дел
Ли Су Ёна, проведение «Года дружбы Россия - КНДР» в наших странах по случаю 70-летия Победы в Великой Отечественной войне и 70-летия Освобождения Кореи, создание Делового совета по сотрудничеству Россия - КНДР, договорённости о запуске ряда взаимовыгодных экономических проектов стали заметным явлением в современных отношениях РФ - КНДР. Однако это оживление связей достаточно хорошо знакомо специалистам по Корее. Северная Корея довольно часто использовала тактику балансирования, отдавая предпочтение то Москве, то Пекину в зависимости от конъюнктуры. Ким Ир Сен был мастером внешнеполитического маневра. Сегодня ситуация для КНДР складывается в пользу такого маневра. В этих условиях важно попытаться убедить Пхеньян проявить гибкость в подходе к политическому разрешению ядерной проблемы, что, естественно, позволило бы продвинуть крупные экономические проекты, создать предпосылки для прогресса в корейском урегулировании в целом, укрепления безопасности в регионе.

Как представляется, российскую политику на корейском направлении необходимо строить на основе оправдавшей себя программы В.В. Путина, настойчиво продвигая шестисторонний переговорный процесс. При этом нужно исходить из понимания того, что Пхеньян уже не откажется от ядерных программ. С учётом этого и других обстоятельств можно было бы попытаться перевести диалог по ядерной проблеме КНДР на иранский сценарий, если он, конечно, окажется успешным с точки зрения международного права и требований МАГАТЭ.

России и впредь следует играть собственную роль в корейских делах, не допускать перегибов в подходах к обоим корейским государствам, укреплять свои политические, экономические и военные возможности в Северо-Восточной Азии, противодействуя планам США добиться доминирования в этом стратегически важном для нас регионе. 


\title{
Russia and Korean Peninsula in the New International Situation
}

\author{
Valeriy Denisov, Chief Research Fellow, Center for East Asian and SCO Studies, \\ Institute of International Studies, MGIMO-University \\ 119454, 76 Prospekt Vernadskogo, Moscow, \\ Russia Ambassador of Russia to DPRK (1996-2001). \\ E-mail:valery_denisov@mail.ru
}

\section{Summary}

Recent trends in international situation around Korean peninsula and the policy of main stateactors are being considered. The USA is trying to reinforce its military presence in South Korea. Seoul is seeking to revise its previous agreements with USA in the sphere of nuclear energy. Trilateral interaction (US-Japan-South Corea) on the problem of North Korean nuclear potential is strengthening. US policy towards North Korea is aimed at counteraction to reinforcement of Russian and Chinese influence in the region. At the same time the USA provides support to North-South dialogue while pressurizing North Korea on the issues of human rights and denuclearization.

Pyongyang is concerned with military rapprochement between South Korea and USA and is trying to make North Korean nuclear program an object of bargaining for peaceful settlement on Korean peninsula. North-to-South relations should be regarded as military opposition in spite of constant appeals to peaceful reunification, development of economic and cultural ties etc. Current analysis reveals that both North and South Korea are still far from real progress in this respect.

Chinese factor is essential though Beijing behavior is cautious. After Kim Rong Un rise to power political and economic relations between North and South weakened. Pyongyang is concerned with regular contacts between China and US on North Korea problems. Aggravation of international situation did not lead to decline in China-South Korea relations, though China is against deployment of missile-defence THAAD complexes. Chinese policy in Korea is aimed at sustaining of status-quo in the peninsula and barring collapse of the North Corea regime.

Policy of Russia is invariably based on the principles formulated in 2001. Recently North Korea has revealed intentions to resume political dialogue with Russia, while South Korea is seemingly not interested in broader co-operation with Russia. Up to the author's opinion it is necessary to promote six-sided negotiations process, avoid extremes in approaches to both Korean states, and oppose to US domination in the region.

Key words: North Korea, South Korea, political dialogue, denuclearization, USA, China, Russia, THAAD.

\section{Jumepamypa / References}

1. Псаки: заявление КНДР об отмене ядерных испытаний - скрытая угроза // MIR24.TV. 10.01.2015. [Электронный ресурc]. URL: http://mir24.tv/news/world/11897808

2. PK не намерена размещать THAAD на своей территории // Всемирное радио KBS. 06.02.2015. [Электронный ресурс]. URL: http://world.kbs.co.kr/russian/news/news_Po_detail. $\mathrm{htm} ? \mathrm{No}=37778 \& \mathrm{id}=\mathrm{Po}$

3. Кирьянов $O$. Сеул признался в поддержке антироссийских санкций // Российская газета. 10.02.2015. [Электронный ресурc]. URL: http://www.rg.ru/2015/02/10/seoul-site.html 